\title{
The utricular otoliths, lapilli, of teleosts: their morphology and relevance for species identification and systematics studies*
}

\author{
CARLOS A. ASSIS \\ Instituto de Oceanografia and Departamento de Biologia Animal, Faculdade de Ciências da Universidade de Lisboa, \\ Campo Grande, 1749-016 Lisboa, Portugal. E-mail: carlos.assis@fc.ul.pt
}

\begin{abstract}
SUMMARY: The present study describes the general morphology of the utricular otoliths, lapilli, of teleost fishes, proposes a terminology for their parts, identifies their two major morphological types, provides some examples of their use in species identification, and discusses their usefulness in studies of fish phylogeny and systematics.

Keywords: utricular otoliths, lapillus, morphology, identification, phylogeny, systematics.

RESUMEN: LOS OTOLITOS UTRICULARES, LAPILLI, DE LOS TELEÓSTEOS: SU MORFOLOGÍA Y RELEVANCIA PARA LA IDENTIFICACIÓN DE ESPECIES Y PARA ESTUDIOS DE SISTEMÁTICA. - El presente trabajo describe la morfología general de los otolitos utriculares, lapilli, de los peces teleósteos, propone una terminología para sus partes, identifica sus dos principales tipos morfológicos, aporta algunos ejemplos de su utilización en la identificación de especies, y discute su utilidad en estudios de filogenia y sistemática de peces.
\end{abstract}

Palabras clave: otolitos uticulares, lapillus, morfología, identificación, filogenia, sistemática.

\section{INTRODUCTION}

According to Chaine and Duvergier (1934), the presence of a "stone" in the utriculus of fish, later called the lapillus (plural: lapilli), was first reported by Julius Casserius in 1600. Since then, the knowledge on the morphological characteristics and diversity of utricular otoliths has not increased much, as no detailed morphological study on these otoliths has ever been undertaken (Assis, 2000). During the first half of the $20^{\text {th }}$ century several studies on recent fish otoliths were published. In some of them, the lapilli of a few species were represented (Shepherd,

*Received May 13, 2004. Accepted October 15, 2004.
1910, 1915; Frost, 1925a, b, c, 1926a, b, c, 1927; Sanz Echeverría, 1928, 1929, 1930, 1931, 1932, 1935, 1936, 1941, 1949; Bauzá Rullán, 1956, 1958). Since then, the lapilli of some species, especially those of otophysine fish (which are rather large and robust), have been used in the identification of recent species (Adams, 1940; Tilak, 1963; Mollo, 1981; Martinez and Monasterio de Gonzo, 1991), have been found with relative frequency in the fossil record (Koken, 1884, 1891; Bassoli, 1906; Schubert, 1915; Martin and Weiler, 1954; Frizzell, 1965; Frizzell and Dante, 1965; Frizzell and Koenig, 1973; Nolf, 1976, 1985), and have been collected in shore sediments (Martini and Reichenbacher, 1997). However, no one has yet considered the lapilli of fishes 
to be worthy of a detailed comparative morphological study. The fact that these otoliths are generally very small, not frequently found in geological layers, and rarely identified as fish otoliths in stomach contents or predator food remains, and the belief that their diversity is not significant, may have been the main reasons for their neglect (Assis, 2000). As a result, the morphological diversity of the lapilli is still almost unknown (Frizzell and Koenig, 1973; Nolf, 1976, 1985) and their real potential as sources of taxonomic information remains unevaluated. In order to help in the description of fossil or recent lapilli, essentially from otophysine fishes, some authors (Tilak, 1963; Frizzell, 1965; Frizzell and
Dante, 1965; Frizzell and Koenig, 1973; Nolf, 1976; Mollo, 1981; Martinez and Monasterio de Gonzo, 1991) have arbitrarily assigned provisional terminologies for their parts. Nevertheless, their terminologies are based on a very narrow range of taxa and are too incomplete to be useful. Furthermore, most of the terms proposed are similar to those already in use for features of the sagittae. It is in this context that this account of the lapilli of fishes aims to: (1) introduce the general morphology of the lapilli of teleosts; (2) propose a terminology for their parts; and (3) evaluate and discuss the potential of their use in species identification and their relevance in taxonomic and phylogenetic studies.

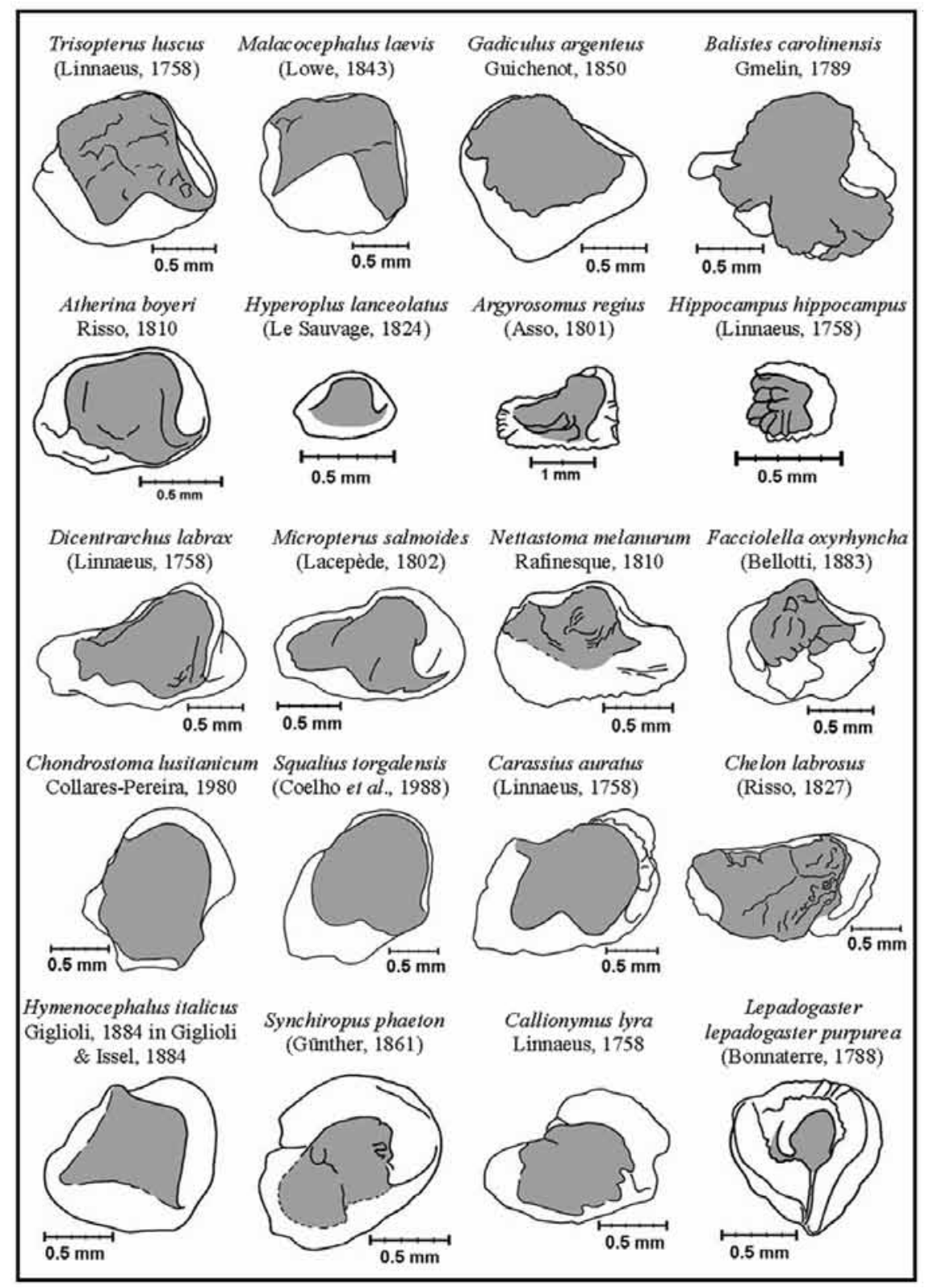

FIG. 1. - Ventral face of the right lapilli of several teleost fish species. The shaded area corresponds to the gibbus maculae. All specimens with lateral (distal) margin to the top of the page and anterior region to the right. 


\section{MATERIALS AND METHODS}

This study is based on the analysis of a collection of utricular otoliths from 4735 positively identified teleost fish, representing 183 species from 23 orders and 62 families. All specimens were collected in Portuguese coastal waters, estuaries and rivers.

Before dissection, the total length $\left(L_{\mathrm{T}}\right)$ of each specimen was recorded. The otoliths were extracted through ventral dissection of the brain case, cleaned, and stored dry. All drawings were made with a camera lucida, using the most suitable magnification in each case.

\section{RESULTS}

The morphology of the utricular otoliths, the lapilli

The lapilli are normally very small otoliths, more or less equivalent to the asterisci in size. However, due to their generally rounded shape and thickness, they are often less fragile than the other two pairs of otoliths.

While the sagittae and the asterisci have their largest development on a vertical plane, are laterally compressed and have their medial side in contact

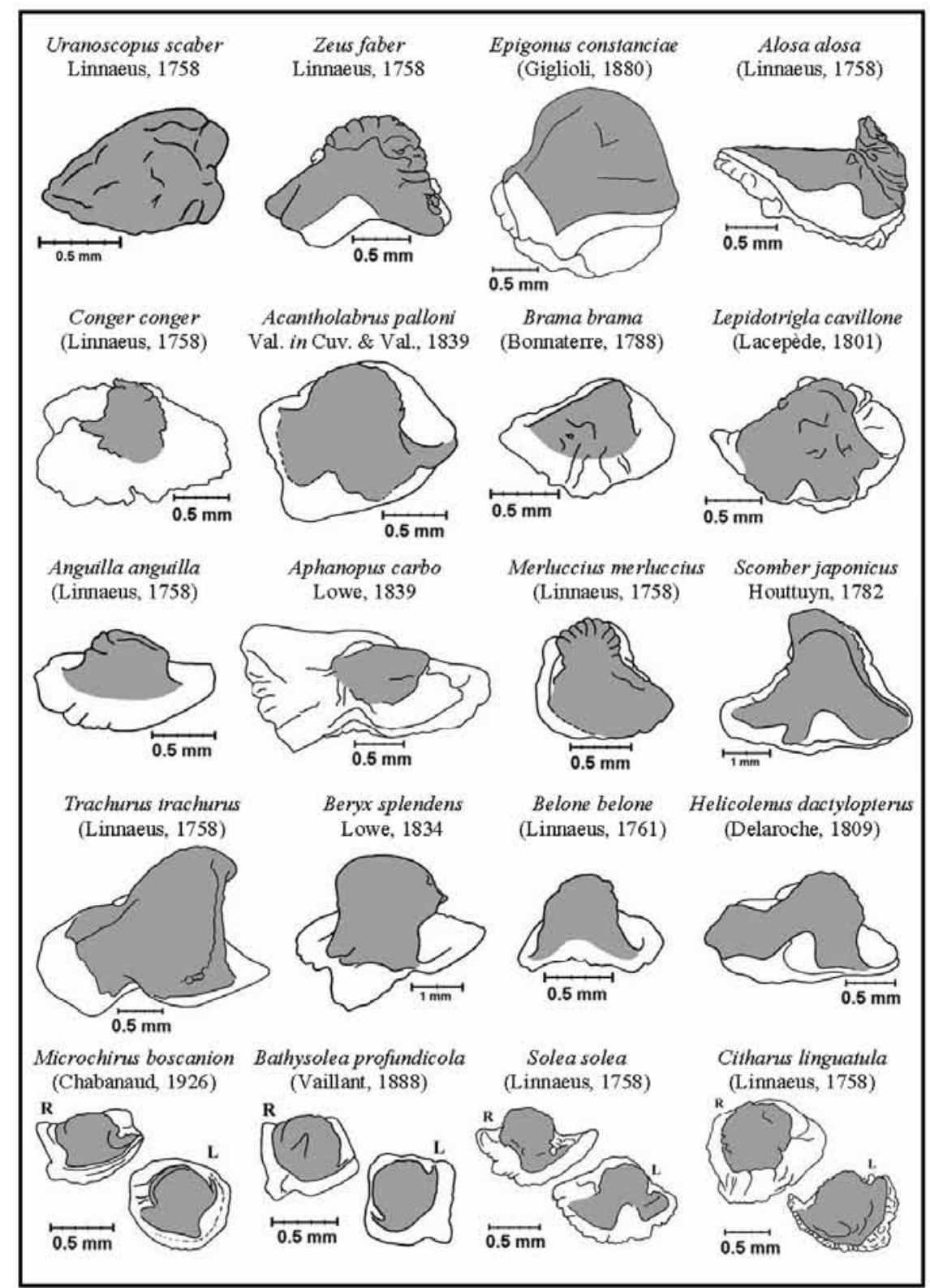

FIG. 2. - Ventral face of the lapilli of several teleost fish species. The shaded area corresponds to the gibbus maculae. The species in the upper four lines are represented by their right otoliths, while the ones in the bottom line are represented by both right (R) and left (L) otoliths. All specimens with lateral (distal) margin to the top of the page; anterior region of the right otoliths to the right and of the left otoliths to the left. 


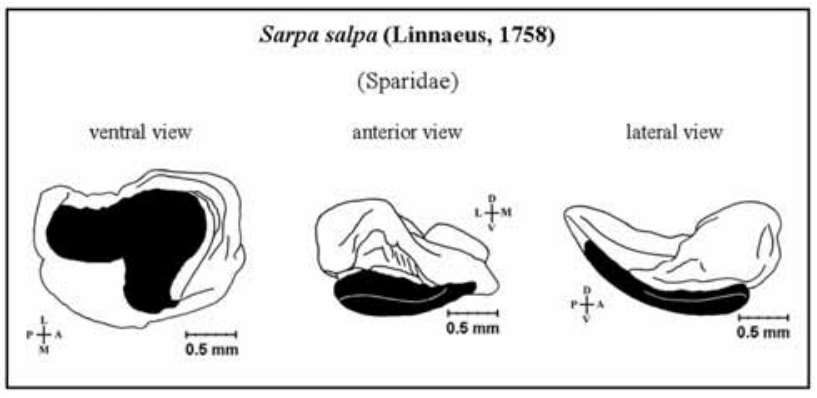

FIG. 3. - Different views of the right lapillus of Sarpa salpa, showing the dorsal body of the otolith (white) and the gibbus maculae (black). D, V, A, P, L and M represent the dorsal, ventral, anterior, posterior, lateral (distal) and medial (proximal) directions respectively.

with the respective maculae, the lapilli have their largest development in a horizontal plane, are dorsoventrally flattened and rest on the macula utriculi, with their ventral face contacting it.

Among the three pairs of otoliths the lapilli are the ones that have the most regular shape, the most homogeneous constitution in all fish taxa and the fewest number of usable diagnostic features. Nevertheless, they are still considerably diverse in terms of morphology (Figs. 1 and 2).

Basically, the lapilli are composed of a wedgeshaped dorsal body, narrowing from the lateral to the medial side, below which occurs a more or less voluminous protuberance (Fig. 3), the gibbus maculae (macular hump). This hump corresponds to the "mond" of Tilak (1963) or the "protubérance dorsale" of Nolf (1976). It develops on the ventral face of the otoliths, may have a diversely shaped outline, tilted antero-laterally with an angulous or globose apex (Fig. 4), and its surface has a texture similar to that of the collicula that pave the sulcus acusticus and the fossa acustica (sensu Assis, 2000, 2003) of the sagittae and asterisci respectively.

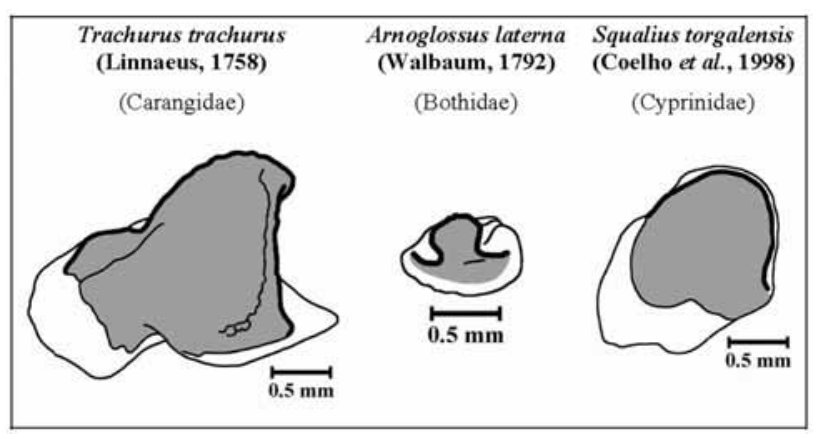

FIG. 4. - Ventral face of the lapilli of three species, illustrating differently shaped gibbi maculae. The gibbi maculae are shaded, and the lateral outline is represented by a heavy line. T. trachurus and $S$. torgalensis are represented by right otoliths (anterior region to the right and lateral margin to the top of the page), while A. laterna is represented by the left otolith (anterior region to the left and lateral margin to the top of the page).

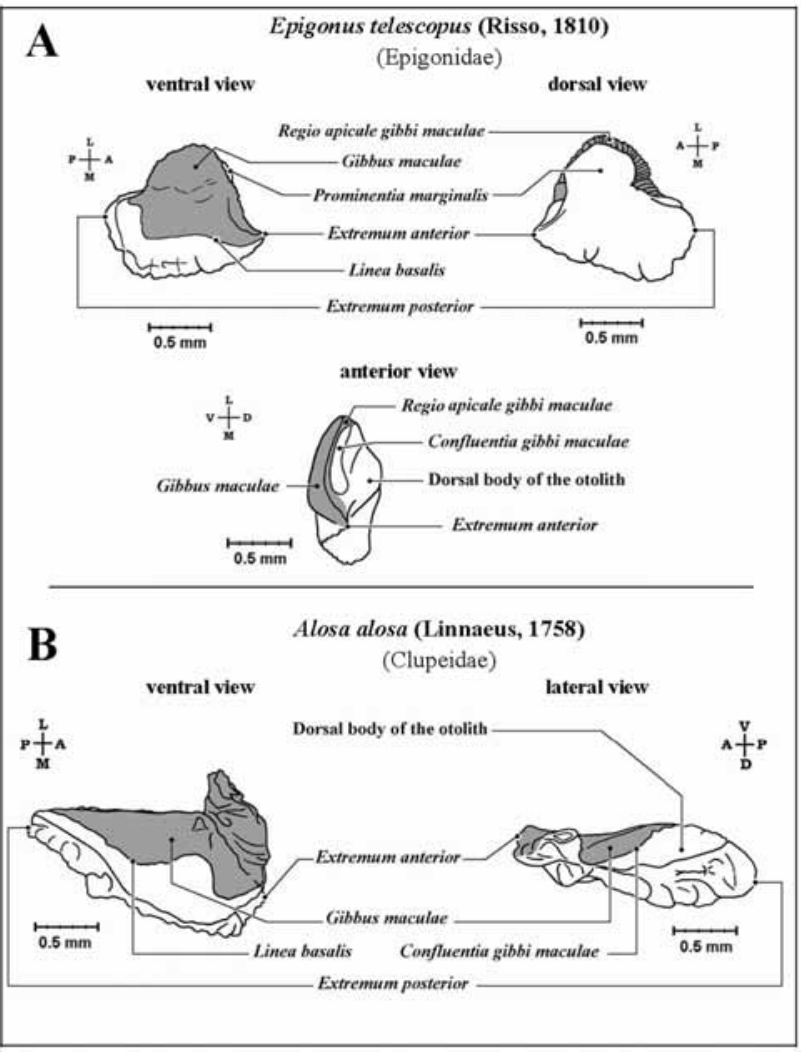

FIG. 5. - Proposed terminology for the features displayed by teleost lapilli. Two types of utricular otoliths are represented: A - a nonclupeiform type otolith, the right lapillus of Epigonus telescopus; B - a clupeiform type otolith, the right lapillus of Alosa alosa. D, V, $\mathrm{A}, \mathrm{P}, \mathrm{L}$ and $\mathrm{M}$ represent the dorsal, ventral, anterior, posterior, lateral (distal) and medial (proximal) directions respectively.

As in the sagittae and asterisci, the anti-macular side may have a plane, regularly curved, or sinuous surface, and is frequently devoid of useful features. For this reason, the macular side (the ventral face in the lapilli) is considered preferential for the observation of these otoliths.

When the lapilli are viewed from their macular side, in a position equivalent to the one occupied in the fish skull observed from bellow, the characteristics of several aspects of the outline can be used in their description (Fig. 5).

The extremum anterior and the extremum posterior (anterior and posterior extremes) are the anterior-most and posterior-most points in the outline of the otolith. Sometimes they are located at the tip of more or less pointed prominences, but often they are the apical points of regular curves.

The prominentia marginalis (marginal swelling) is a more or less conspicuous, normally round swelling of the lateral margin of the dorsal body, along the curvature of the apical region of the gibbus maculae. It frequently corresponds to the thickest zone in the dorsal body of the otolith. 


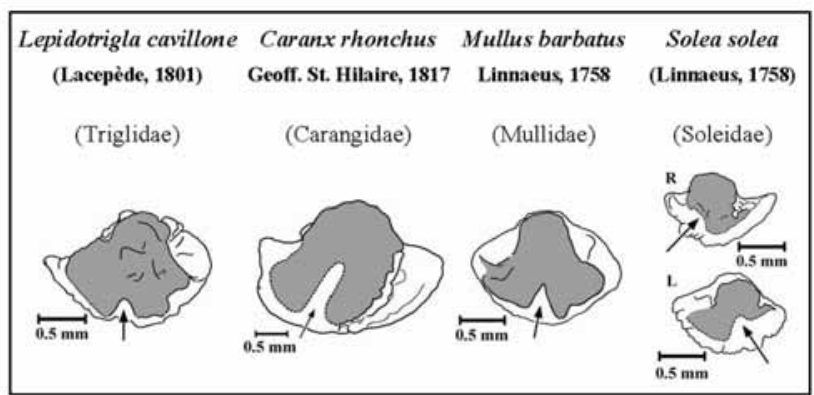

FIG. 6. - Ventral face of the lapilli of four species, illustrating differently shaped incisurae lineae basalis (indicated by the arrows). The shaded areas correspond to the gibbi maculae. L. cavillone, $C$. rhonchus and $M$. barbatus are represented by right otoliths, while $S$. solea is represented by both right $(\mathrm{R})$ and left $(\mathrm{L})$ otoliths. All specimens with lateral (distal) margin to the top of the page; anterior region of the right otoliths to the right, and of the left otolith to the left.

When the gibbus maculae is well developed it may intercept the lateral outline of the dorsal body and totally or partially cover the prominentia marginalis, which becomes only visible from the dorsal face. In such cases, a band of the dorsal surface of the gibbus maculae, the regio apicale gibbi maculae (apical region of the macular hump), is visible on the outside of the lateral outline of the dorsal body.

The structure that several authors (Adams, 1940; Tilak, 1963; Frizzell, 1965; Frizzell and Dante, 1965; Frizzell and Koenig, 1973; Mollo, 1981) have called the sulcus in the lapilli rarely looks like a furrow and is not associated with the sensitive epithelium of the macula in the same way that the sulcus acusticus or the fossa acustica (sensu Assis, 2000, 2003) are in the other pairs of otoliths. Instead, it simply represents the region of contact between the lateral margins of the gibbus maculae and the dorsal body of the otolith. Confluentia gibbi maculae (confluence of the macular hump) is the proposed designation for this feature, which probably corresponds to the zone of the otolith adjacent to the striola, a thicker region of the utricular epithelium with larger cells that occurs around the dorso-lateral border of the macula utriculi (Popper and Platt, 1993).

The linea basalis (basal line) is not equally clear in all otoliths, especially its medial portion, which may be inconspicuous or interrupted. This line corresponds to a discontinuity in texture, sometimes associated with a small slope or step, and seems to represent the limits of the zone of contact between the otolith and the macula utriculi, or the limits of the collicular region of the gibbus maculae. Frequently, the linea basalis displays a more or less pronounced, diversely shaped indentation directed to the middle of the surface of the gibbus maculae, the incisura lineae basalis (indentation of the basal line) (Fig. 6).

\section{The two morphological types of lapilli}

In morphological terms, two very distinct types of lapilli can be defined: the clupeiform and the nonclupeiform types.

The clupeiform type of lapilli is a highly modified otolith, found only among the clupeiform fishes. It is characterised by a tetrahedrical shaped dorsal body, an extremely thin and sometimes inconspicuous gibbus maculae, with a very thin and fragile extension projecting beyond the anterior border of the dorsal body in an antero-lateral and ventral direction, and an almost inconspicuous confluentia gibbi maculae (Figs. $5 \mathrm{~B}$ and 7).

The non-clupeiform type of lapilli, which occurs in most fish taxa, is characterised by a diversely shaped dorsal body (although never tetrahedrical), a normally voluminous and conspicuous gibbus maculae in the ventral surface of the dorsal body, and a marked confluentia gibbi maculae (Figs. $5 \mathrm{~A}$ and 8).

\section{The potential of the lapilli in fish species identification}

The characteristics of the lapilli, like those of any other anatomical part of a fish, are subjected to a considerable diversity and can be used as an aid in species identification, provided that their vari-

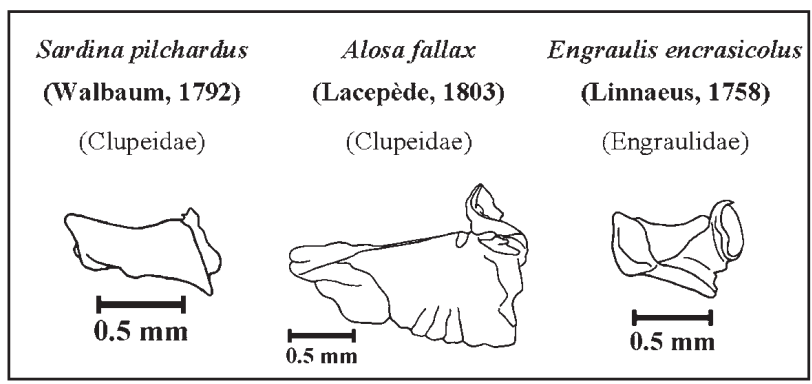

FIG. 7. - Ventral face of right, clupeiform type lapilli. All otoliths with lateral margin to the top of the page and anterior region to the right.

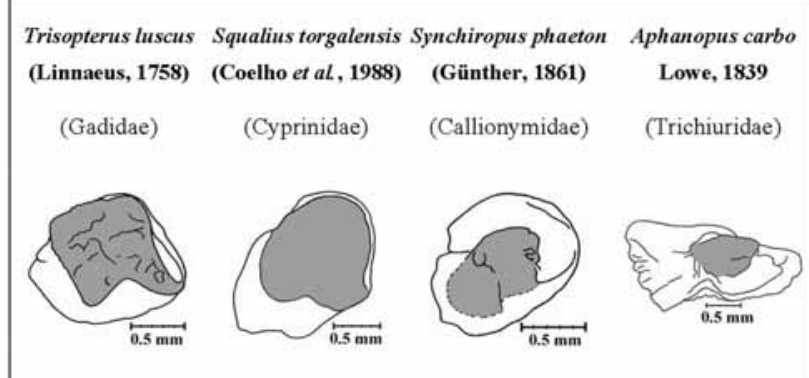

FIG. 8. - Ventral face of right, non-clupeiform type lapilli. The shaded areas correspond to the gibbi maculae. All otoliths with lateral margin to the top of the page and anterior region to the right. 
ability is lower than the diversity, i.e. that the otoliths from co-specific fish are more alike than those of different species, even if the species are closely related.

The examples from the rather unrelated families Berycidae, Mugilidae and Sparidae, presented as an appendix to the present work, show that, although with different degrees of precision, and at least in some taxa, the morphology of the lapilli is sufficiently specific to allow them to be used as a tool in fish species identification.

Although the diversity of those examples and the variability illustrated in each of them are rather limited, the three cases presented point out the specific nature of some combinations of morphological characteristics of the lapilli, which may enable them, at least in some cases, to be of use in the discrimination between species. Among the characteristics that enter the combination, the general shape of the otolith and the characteristics related to the gibbus maculae, the prominentia marginalis, the linea basalis, and its incisura, seem to be the most relevant in terms of discriminative power.

\section{The potential of the lapilli in studies of fish phylogeny and systematics}

In contrast to the sagittae and asterisci, the lapilli show a noticeable structural homogeneity in almost every taxon studied. This indicates that they are anatomical parts with an extremely conservative general morphology.

Only among the clupeiforms do the lapilli assume a completely modified morphology, a fact that is probably related to the particular otophysic connection developed between the gas bladder and the utriculi in this group (Grassé, 1958; Popper and Platt, 1979; Nelson, 1994; Bond, 1996). Different from the otoliths of other taxa, the clupeiform lapilli have a tetrahedric shaped dorsal body with a narrow lateral margin, a broad medial margin, a concave curvature in the ventral face, and an extremely thin gibbus maculae with an anterior extension that projects beyond the dorsal body (Figs. 5b and 7).

The specificity and the probable universality of this type of lapillus among the Clupeiformes allow its peculiarities to be added to the synapomorphies that define the group, and to the arguments that support its holophyly.

With the exception of the clupeiforms, however, no morphological characteristic of the known diver-

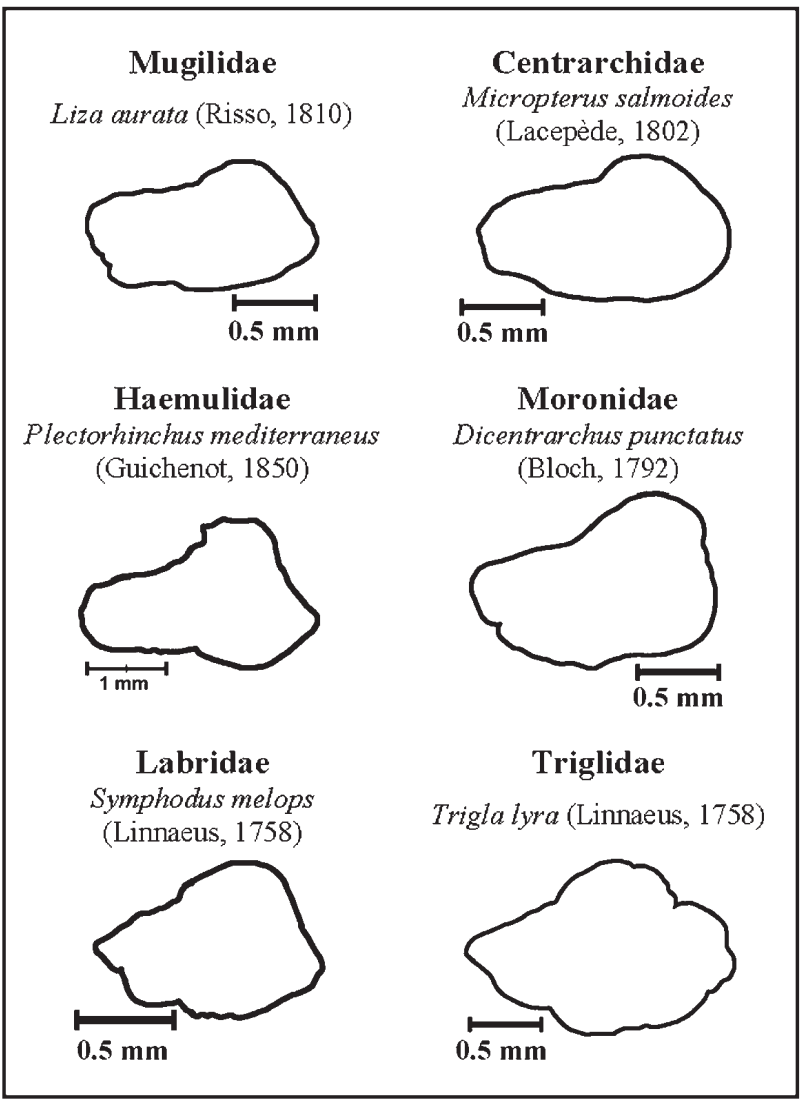

FIG. 9. - Outline of the right lapilli of several species, illustrating the occurrence of otoliths with similar appearance in rather unrelated fish taxa. All outlines are represented with lateral margin to the top of the page and anterior region to the right.

sity of the lapilli seems to display a clear tendency among the Teleostei, or to be specific of one higher level taxon in particular. This suggests that the lapilli may be of limited utility in studies of fish macroevolution and macrosystematics.

Nevertheless, the fact that some morphological features of the lapilli can be used to discriminate and identify with reasonable precision some fish taxa points to the possibility of their use, along with other characteristics, in the establishment of phylogenetic/systematic relationships between closely related species.

In this respect, each of the morphological features of the otolith, per se, seems to be of little diagnostic value at a high taxonomic level, but increases in discriminative power below the family level. In fact, the occurrence of otoliths with similar characteristics, for instance outline, is common in distantly related taxa (Fig. 9), as well as with different corresponding characteristics within the same lower ranked taxon (Fig. 10). The same is true for all the other relevant features displayed by these otoliths (the gibbus maculae, the prominentia 


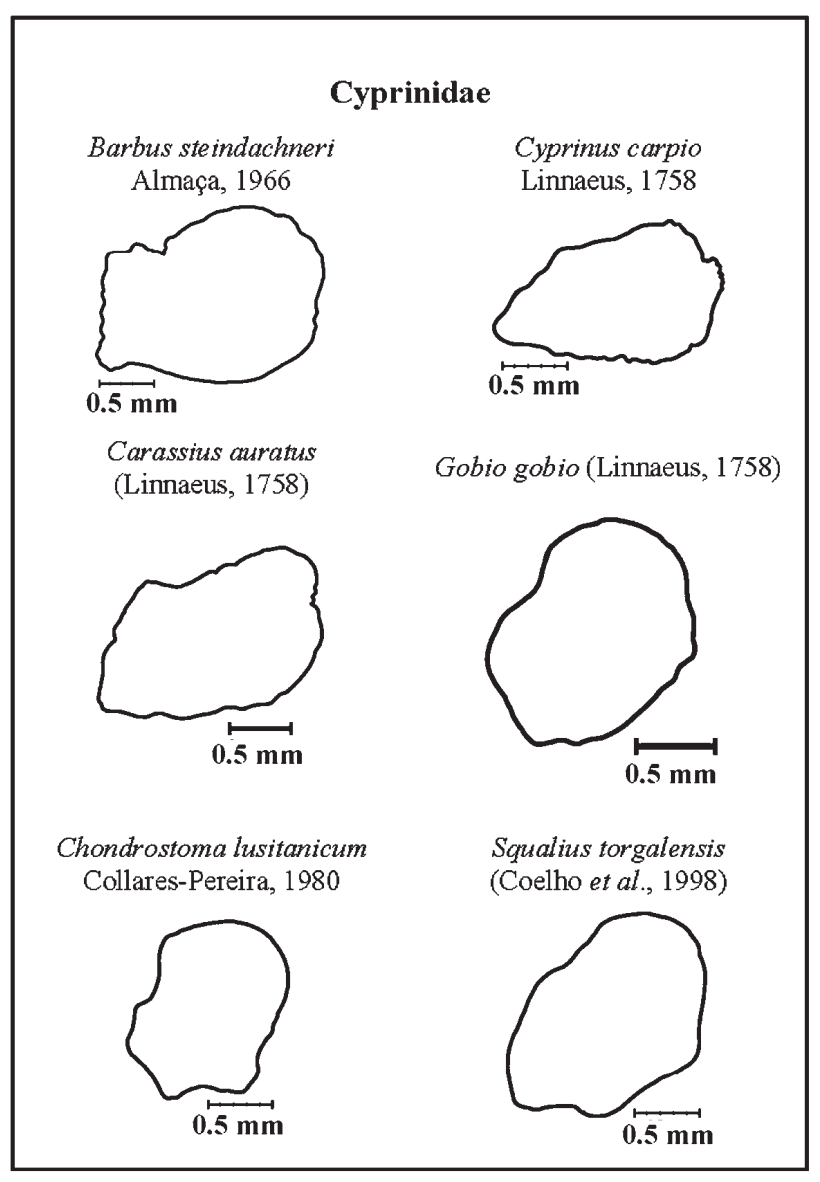

FIG. 10. - Outline of the right lapilli of several cyprinid species, illustrating the occurrence of otoliths with considerably different appearance within the same fish taxon. All outlines are represented with lateral margin to the top of the page and anterior region to the right.

marginalis, the linea basalis, the incisura lineae basalis, etc.).

This causes the diversity among higher level taxonomic groups to overlap considerably, and makes it necessary to combine all available characters when using the morphology of the lapilli for purposes of taxon characterisation or identification. For this reason, the information given by the characteristics of the lapilli, in terms of the study of phylogenetic relations, might be limited in relevance to the relationships between taxa positioned at the lower levels of the taxonomic hierarchy.

Above all, the low number of usable characteristics is probably related to the lower complexity of the macula utriculi in comparison with the maculae sacculi and lagenae, which causes the associated parts of the respective otoliths, i.e. the sulcus acusticus, the fossa acustica and the gibbus maculae, to differ significantly in the degree of differentiation and, consequently, in the number of usable diagnostic features.

\section{DISCUSSION}

In 1868, Higgins described the "superior" otolith, as he then called the lapillus, as an amorphous stone, completely devoid of value in studies of fish classification, phylogeny and palaeontology, and so unspecific that it would not even be usable for purposes of species identification. His arguments were that the utricular otoliths: (1) are normally rather small; (2) are very difficult to extract from the fishes' heads; (3) are not found in the fossil record or in the stomach contents or excrements of piscivorous animals; and (4) are too homogeneous in terms of shape.

Since that period, Higgins's (1868) statement has been reinforced by the inexistence of studies on the comparative morphology of the lapilli, and stressed by some authors who have subscribed to some of his arguments (e.g. Rado, 1968; Stinton, 1968; Jonet, 1972/73; Popper and Coombs, 1982).

Although the lapilli are normally rather small, if the fish skulls are carefully dissected and the relative position of each pair of otoliths is known, their retrieval does not involve any major difficulties. For this purpose, the ventral dissection of the otic region of the neurocranium has proven to be the best method for exposing the membranous labyrinth from underneath and extracting the otoliths (Assis, 2000, 2003).

It is true that the presence of lapilli in the fossil record has not been reported with as much frequency as that of sagittae, and that no published reference is known concerning their occurrence in the stomach contents or excrements of piscivorous animals. Nevertheless, many palaeontologists have reported the occurrence of fossil lapilli in geological strata from Europe (e.g. Koken, 1884, 1991; Bassoli, 1906; Priem, 1906; Schubert, 1915; Martin and Weiler, 1954; Paghida, 1962; Weiler, 1963; Martini, 1965a, b; Stinton, 1977; Jonet, 1979; Nolf and Lapierre, 1979; Nolf and Capetta, 1980; Steurbaut, 1984; Reichenbacher and Mödden, 1996), from the Americas (e.g. Frizzell, 1965; Frizzell and Dante, 1965; Frizzell and Koenig, 1973; Nolf, 1976; Nolf and Stringer, 1996; Martini and Reichenbacher, 1997; Nolf and Aguilera, 1998) and from New Zealand (e.g. Schwarzhans, 1980), and the author of the present work has had the opportunity to identify two lapilli from Atherina sp. and Pomatoschistus sp. from stomach contents of green crabs, Carcinus maenas (Linnaeus, 1758), from the Tagus estuary, and two myctophid lapilli from stomach contents of 
blackmouth catsharks, Galeus melastomus Rafinesque, 1810, captured in the eastern north Atlantic.

This shows that lapilli may be found both in the fossil record and in stomach contents of marine predators. What remains to be known is the extent to which their occurrence is, in fact, rare or whether they have been neglected or considered as unidentified material in other works.

It is also true that the lapilli are morphologically rather homogeneous among most fish groups, and that the number of taxonomically usable features in these otoliths is fewer than in the other pairs, especially if the sagittae are used for comparison. However, even if there are taxa that cannot be discriminated trough the morphological characteristics of the respective lapilli, as shown before, these otoliths may be used with considerable precision in the identification of at least some other teleost groups (Adams, 1940; Tilak, 1963; Mollo, 1981; Martinez and Monasterio de Gonzo, 1991; Assis, 2000).

An exception to the morphologic homogeneity of the lapilli among the teleosts is the case of the clupeiforms, in which there is a close association between the gas bladder and the utriculus (Allen et al., 1976; Denton and Blaxter, 1976; Best and Gray, 1980, 1982; Popper and Coombs, 1982; Popper and Platt, 1993), related to an enhanced involvement of this chamber in sound perception (Popper and Platt, 1979), and justifying the fact that their lapilli have evolved to assume a morphology completely different from that of the otoliths of other teleosts.

At least in the case of the sagittae, it is known that otolith morphology is not only related to common ancestry (Schwarzhans, 1978; Gaemers, 1984; Nolf, 1985, 1993; Lombarte and Castellón, 1991), but also to the habitat in which the fish live (Wilson, 1985; Volpedo and Echeverría, 2003) and to the anatomical specialisations connected with sound perception, such as the structure of the entire inner ear (Nolf, 1985, 1993; Popper and Platt, 1993; Lychakov and Rebane, 2000; Popper and Lu, 2000; Lombarte and Popper, 2004). They are thus subjected to different degrees of morphologic convergence between evolutionary distant taxa, and divergence between evolutionary close ones (Nolf, 1985, 1993). The same probably happens with the asterisci (Assis, 2003) as both the sacculus and the lagena are especially engaged in sound detection (Popper, 1980; Rogers et al., 1988) and seem to have evolved in close association with specialisations of the sense of hearing (Popper and Coombs, 1982). On the con- trary, the utriculus and the remaining pars superior appear to be more engaged in the sense of posture and have a very homogeneous structure among all vertebrates (Cordier and Dalcq, 1954; Popper and Coombs, 1982). It is therefore not surprising that the lapilli have such a homogeneous morphology.

Although it ought to be kept in mind that otolith morphology alone should not be used to define taxonomic or phylogenetic affinities (Schwarzhans, 1978; Nolf, 1985, 1993, 1995; Smale et al., 1995), there is no objective reason for the characteristics presented by the otoliths, when available, not to be used along with other characters of the fish body to increase the amount of information available in studies of fish systematics and phylogeny, as already proposed by Adams (1940).

In this respect, it is important to note that, as in the other two pairs of otoliths, some of the most relevant discriminative characters of the lapilli are those associated with the otolith outline and with the region that contacts the sensitive macula, which most certainly reflect its shape. Among them, the shapes of the gibbus maculae, of the linea basalis, and of the incisura lineae basalis assume a particular importance.

However, due to the morphological homogeneity of the utriculus among fish, and probably also to the little differentiation of the macula utriculi, most of the diversity of the lapilli is related to details less evident than those that characterise the other pairs of otoliths.

While it is true that the lapilli have a limited number of usable morphological features, and that no clear tendency in character distribution has yet been noticed among the teleosts, it is evident that these otoliths can be used for purposes of identification, in some cases to the species level.

For the above reasons, it is natural that the knowledge on the morphologic diversity of the utricular otoliths, which is still very poorly known and of limited use in the deduction of phylogenetic relationships and for taxonomic studies at the higher levels of classification, may prove to be a valuable tool in fish species identification and as a source of additional phylogenetic and taxonomic information at the family, genus and species levels. To deal with these limitations, future work directed towards an increase in the range of taxa studied and the evaluation of the amount of intra- and interspecific variation associated with the features of these otoliths is necessary before their real potential as taxonomic tools can be properly evaluated. 


\section{ACKNOWLEDGEMENTS}

I thank Dr. José Vasconcelos, a Latin and Greek teacher, for his assistance in the construction of the Latin names used in this paper, and Dr. D. Nolf for his suggestions to improve a previous version of this manuscript. I also thank Dr. Rosa Reboreda for the correction of the Spanish version of the title and abstract, and the anonymous referees who contributed to the final version of the present report. This work was partially funded by the Fundação para a Ciência e a Tecnologia in the framework of the Multi-Year Programme.

\section{REFERENCES}

Adams, L.A. - 1940. Some characteristic otoliths of American Ostariophysi. J. Morphol., 66: 497-527.

Allen, J.M., J.H.S. Blaxter and E.J. Denton. - 1976. The functional anatomy and development of the swimbladder-inner ear-lateral line system in herring and sprat. J. Mar. Biol. Assoc. U. K., 56: 471-486.

Assis, C.A.S. - 2000. Estudo Morfológico dos Otólitos Sagitta, Asteriscus $e$ Lapillus de Teleósteos (Actinopterygii, Teleostei) de Portugal Continental. Sua Aplicação em estudos de Filogenia, Sistemática e Ecologia. PhD thesis, Univ. Lisbon.

Assis, C.A. - 2003. The lagenar otoliths of teleosts: their morphology and its application in species identification, phylogeny and systematics. J. Fish Biol., 62: 1268-1295.

Bassoli, G.G. - 1906. Otoliti fossili terziari dell'Emilia. Riv. Ital. Paleont, $12 \cdot 36-56$

Bauzá Rullán, J. - 1956. Notas sobre otolitos de peces actuales. Bol. R. Soc. Esp. Hist. Nat. (Secc. Biol.), 54: 119-133.

Bauzá Rullán, J. - 1958. Otolitos de peces actuales. Bol. R. Soc. Esp. Hist. Nat. (Secc. Biol.), 56: 111-126.

Best, A.C.G. and J.A.B. Gray. - 1980. Morphology of the utricular recess in the sprat. J. Mar. Biol. Assoc. UK, 60: 703-715.

Best, A.C.G. and J.A.B. Gray. - 1982. Nerve fibre and receptor counts in the sprat utriculus and lateral line. J. Mar. Biol. Assoc. UK, 62: 201-213.

Bond, C. E. - 1996. Biology of Fishes. Saunders College Publishing, Fort Worth.

Chaine, J. and J. Duvergier. - 1934. Recherches sur les otolithes des poissons. Étude descriptive et comparative de la sagitta des téléostéens. Actes Soc. Linn. Bordeaux 86: 5-254.

Cordier, R. and A. Dalcq. - 1954. Organe Stato-Acoustique. In: P.P Grassé (ed.), Traité de Zoologie, Vol. XII, pp. 453-521. Masson and Cie, Paris.

Denton, E.J. and J.H.S. Blaxter. - 1976. The mechanical relationships between the clupeid swimbladder, inner ear and lateral line. J. Mar. Biol. Assoc. UK, 56: 787-807.

Frizzell, D.L. - 1965. Otoliths of new fish (Vorhisia vulpes, n. gen., n. sp. Siluroidei?) from Upper Cretaceous of South Dakota. Copeia, 1965: 178-181.

Frizzell, D.L. and J.H. Dante. - 1965. Otoliths of some early Cenozoic fishes of the Gulf Coast. J. Paleont., 39: 687-718.

Frizzell, D.L. and J.W. Koenig. - 1973. Upper Cretaceous ostariophysine (Vorhisia) redescribed from unique association of utricular and lagenar otoliths (lapillus and asteriscus). Copeia, 1973: 692-698.

Frost, G.A. - 1925a. A comparative study of the otoliths of the neopterygian fishes. Ann. Mag. Nat. Hist. (ser. 9), 15: 152-163.

Frost, G.A. - 1925b. A comparative study of the otoliths of the neopterygian fishes. Ann. Mag. Nat. Hist. (ser. 9), 15: 553-561.

Frost, G.A. - 1925c. A comparative study of the otoliths of the neopterygian fishes. Ann. Mag. Nat. Hist. (ser. 9), 16: 433-446.

Frost, G.A. - 1926a. A comparative study of the otoliths of the neopterygian fishes. Ann. Mag. Nat. Hist. (ser. 9), 18: 465-482.

Frost, G.A. - 1926b. A comparative study of the otoliths of the neopterygian fishes. Ann. Mag. Nat. Hist. (ser. 9), 18: 99-104.

Frost, G.A. - 1926c. A comparative study of the otoliths of the neopterygian fishes. Ann. Mag. Nat. Hist. (ser. 9), 18: 483-490.

Frost, G.A. - 1927. A comparative study of the otoliths of the neopterygian fishes. Ann. Mag. Nat. Hist. (ser. 9), 19: 439-445.

Gaemers, P.A.M. - 1984. Taxonomic position of the Cichlidae (Pisces, Perciformes) as demonstrated by the morphology of their otoliths. Neth. J. Zool., 34: 566-595.

Grassé, P.P. - 1958. L'Oreille et ses Anexes. In: P. P. Grassé (ed.), Traité de Zoologie, vol. XIII, pp. 1063-1098. Masson and Cie, Paris.

Higgins, E.T. - 1868. On the otoliths of fish, and their value as a test in verifying recent and fossil species. J. Linn. Soc., 9: 157-166.

Jonet, S. - 1972/73. Étude des otolithes des téléostéens (Pisces) du Miocène des environs de Lisbonne. Comunic. Serv. Geol. Portugal, 56: 107-294.

Jonet, S. - 1979. Le Tortonien supérieur (TVIIb) des environs de Fonte da Telha (Péninsule de Setúbal) et ses faunes. $2^{\mathrm{e}}$ partie: Les otolithes des poissons Téléostéens. Comunic. Serv. Geol. Portugal, 65: 105-130.

Koken, E. - 1884. Über Fisch-Otolithen, insbesondere über diejenigen der norddeutschen Oligocän-Ablagerungen. Z. Dt. Geol. Ges., 36: 500-565.

Koken, E. - 1891. Neue Untersuchungen and Tertiären Fischotolithen, II. Z. Dt. Geol. Ges., 43: 77-170.

Lombarte, A. and A. Castellón. - 1991. Interspecific and Intraspecific otolith variability in the genus Merluccius as determined by image analysis. Can. J. Zool., 69: 2442-2449.

Lombarte, A. and A.N. Popper. - 2004. Quantitative changes in the otolithic organs of the inner ear during the settlement period in European hake Merluccius merluccius. Mar. Ecol. Prog. Ser., 267: 233-240.

Lychakov, D.V. and Y.T. Rebane. - 2000. Otolith regularities. Hear. Res., 143: 83-102.

Martínez, V. and G. Monasterio de Gonzo. - 1991. Clave de identificacion de algunos peces siluriformes en base al estudio de sus otolitos. Rev. Asoc. Cienc. Nat. Litor., 22: 95-118.

Martin, G.P.R. and W. Weiler. - 1954. Fisch-Otolithen aus dem deutschen Mesozoikum (Dogger bis Wealden). Senck. Leth., 35: $119-192$.

Martini, E. - 1965a. Die Fischfauna von Sieblos/Rhön (Oligozän). 1: Smerdis-Skelette mit Otolithen in situ. Senck. Leth., 46a: 291-305.

Martini, E. - 1965b. Die Fischfauna von Sieblos/Rhön (Oligozän). 2: Fischreste aus Koprolithen. Senck. Leth., 46a: 307-314.

Martini, E. and B. Reichenbacher. - 1997. Fish-remains, especially otoliths, in recent shore sediments of the Salton Sea, Califórnia. Cour. Forsch.-Inst. Senckenberg, 201: 277-293.

Mollo, S.M. - 1981. Otolitos de peces de la laguna Chascomus (Provincia de Buenos Aires). Analisis y consideraciones para su identificacion en estudios troficos. Limnobios, 2: 253-263.

Nelson, J.S. - 1994. Fishes of the World. John Wiley and Sons, New York.

Nolf, D. - 1976. Les otolithes des téléostéens néogènes de Trinidad. Eclogae Geol. Helv., 69: 703-742.

Nolf, D. - 1985. Otolithi piscium. In: H.P. Schultze (ed.), Handbook of Paleontology, 10. Fischer Verlag, Stuttgart.

Nolf, D. - 1993. A survey of Perciform otoliths and their interest for phylogenetic analysis, with an iconographic synopsis of the Percoidei. Bull. Mar. Sci., 52: 230-239.

Nolf, D. - 1995. Studies on fossil otoliths - the state of the art. In: D.H. Secor, J.M. Dean and S.E. Campana (eds.), Recent Developments in Fish Otolith Research, pp. 513-544. University of South Carolina Press, Columbia

Nolf, D. and O. Aguilera. -1998 . Fish otoliths from the Cantaure Formation (Early Miocene of Venezuela). Bull. Inst. Roy. Sci. Nat. Belg. (Sciences de la Terre), 68: 237-262.

Nolf, D. and H. Capetta. - 1980. Les otolithes de Téléostéens du Miocène de Montpeyroux (Hérault, France). Palaeovertebrata, 10: $1-28$.

Nolf, D. and H. Lapierre. - 1979. Otolithes de poissons nouveaux ou peu connus du Calcaire Grossier et de la Formation d'Auvres (Eocène du Bassin parisien). Bull. Mus. Nat. Hist. Nat. Paris (4' série), 1C: 79-125.

Nolf, D. and G.L. Stringer. - 1996. Cretaceous fish otoliths - a synthesis of the North American record. In: G. Arratia and G. Viohl (eds.), Mesozoic fishes - Systematics and paleoecology, pp. 433-459. Verlag Dr. Friedrich Pfeil, München. 
Paghida, N. - 1962. Otolitele din buglovianul Podesului Moldovenese. Anal. Stiint. Univ. Al I. Cuza (Sect. 2), 8: 13-20.

Popper, A.N. - 1980. Scanning electron microscopic study of the sacculus and lagena in several deep-sea fishes. Am. J. Anat., 157: $115-136$.

Popper, A.N. and S. Coombs. - 1982. The morphology and evolution of the ear in Actinopterygian fishes. Am. Zool., 22: 311328.

Popper, A.N. and Z. Lu. - 2000. Structure-function relationships in fish otolith organs. Fish. Res., 46: 15-25.

Popper, A.N. and C. Platt. - 1979. The herring ear has a unique receptor pattern. Nature, 280: 832-833.

Popper, A.N. and C. Platt - 1993. Inner ear and lateral line. In: D.H. Evans (ed.), The Physiology of Fishes, pp. 99-136. CRC Press, Boca Raton.

Priem, F. - 1906. Sur les otolithes des poissons Éocènes du bassin Parisien. Bull. Soc. Géol. France (4e sér.), 6: 265-280.

Rado, G. - 1968. Étude des otolithes sarmatiens de Copacel-Chijic (Bassin du Crisul Repede). Trav. Mus. Hist. Nat. Grigore Antipa, 8: 581-585.

Reichenbacher, B. and C. Mödden. - 1996. Biostratigraphie und Paläoökologie aufgrund von Fisch-Otolithen in den Oberen Cerithienschichten (Unter-Miozän) bei Göllheim (Mainzer Becken). Mainzer Geowiss. Mitt., 25: 89-110.

Rogers, P.H., A.N. Popper, M.C. Hastings and W.M. Saidel. 1988. Processing of acoustic signals in the auditory system of bony fish. J. Acoust. Soc. Am., 83: 338-349.

Sanz Echeverría, J. - 1928. Investigaciones sobre otolitos de peces de España. Subord. Clupeiformes y Anguiliformes. Bol. R. Soc. Esp. Hist. Nat., 28: 159-166.

Sanz Echeverría, J. - 1929. Investigaciones sobre otolitos de peces de Melilla. Bol. R. Soc. Esp. Hist. Nat., 29: 71-80.

Sanz Echeverría, J. - 1930. Investigaciones sobre otolitos de peces de España. Bol. R. Soc. Esp. Hist. Nat., 30: 173-178.

Sanz Echeverría, J. - 1931. Investigaciones sobre otolitos de peces de España. Bol. R. Soc. Esp. Hist. Nat., 31: 369-374.

Sanz Echeverría, J. - 1932. Sobre otolitos de los apogónidos. Bol. R. Soc. Esp. Hist. Nat., 32: 151-154.

Sanz Echeverría, J. - 1935. Otolitos de los peces Gadiformes de España. Bol. R. Soc. Esp. Hist. Nat., 35: 245-274

Sanz Echeverría, J. - 1936. Otolitos del género Mullus. Bol. R. Soc. Esp. Hist. Nat., 36: 345-361.

Sanz Echeverría, J. - 1941. Investigaciones sobre otolitos de peces de España (fams. Cepolidae, Pomacentridae y Ophidiidae). Bol. R. Soc. Esp. Hist. Nat., 39: 345-352.

Sanz Echeverría, J. - 1949. Identificación de los peces de la familia Centrolophidae de España por medio de los otolitos. Bol. R. Soc. Esp. Hist. Nat. (tomo extraordinario), 151-156.

Schubert, R.J. - 1915. Oberocäne Otolithen von Barton-Cliff bei Christchurch (Hampshire). Jb. K. K. Geol. Reichsanst., 65: 277289

Schwarzhans, W. - 1978. Otolith-morphology and its usage for higher systematical units, with special reference to the Myctophiformes s.1. Meded. Werkgr. Tert. Kwart. Geol., 15: 167185

Schwarzhans, W. - 1980. Die Tertiäre Teleosteer-Fauna Neuseelends, rekonstruiert anhand von Otolithen. Berliner Geowiss. Abh. (A), 26: 1-211.

Shepherd, C.E. - 1910. Comparisons of otoliths found in fishes. Zoologist (ser. 4), 14: 292-298.

Shepherd, C.E. - 1915. The "Lapillus" in fishes. Zoologist (ser. 4), 19: $257-262$.

Smale, M.J., G. Watson and T. Hecht. - 1995. Otolith atlas of Southern African marine fishes. Ichthyol. Monogr. J.L.B. Smith Inst. Ichthyol., 1: 1-253.

Steurbaut, E. - 1984. Les otolithes de téléostéens de l'OligoMiocène d'Aquitaine (Sud-Ouest de la France). Palaeontographica (A), 186: 1-162.

Stinton, F.-C. - 1968. On the study of Tertiary fish otoliths. Mém. Bur. Rech. Géol. Min., 58: 153-162.

Stinton, F. - 1977. Fish Otoliths from the English Eocene (Part 2). Palaeontogr. Soc. Monogr., 130: 57-126.

Tilak, R. - 1963. Studies on the comparative morphology of the otoliths of Indian siluroids. Zool. Anz., 173: 181-201.

Volpedo, A. and D. D. Echeverría. - 2003. Ecomorphological patterns of the sagitta in fish on the continental shelf off Argentine. Fish. Res., 60: 551-560.

Weiler, W. - 1963. Die fisch fauna des Tertiärs im oberrheinischen Graben, des Mainzer Beckens, des unteren Maintals und der Wetterau, unter besonderer Berücksichtigung des Untermiozäns. Abh. Senckenb. Naturf. Ges., 504:1-75.

Wilson Jr., R.R. - 1985. Depth-related changes in sagitta morphology in six macrourid fishes of the Pacific and Atlantic Oceans. Copeia, 4: 1011-1017.

Scient. ed.: B. Morales-Nin 


\section{APPENDIX}

The use of the otoliths lapillus in fish species identification. Examples from the genus Beryx and from the families Mugilidade and Sparidae

\section{The lapilli of the genus Beryx (Berycidae)}

The utricular otoliths of the two european Beryx species (Fig. 11) are characterised by an irregular shape, with a lobed medial margin. They have a long and triangular anterior region, with a pointed extremum anterior; a longitudinal axis closer to the medial side than to the lateral one; a large prominentia marginalis individualised from the rest of the dorsal body by a conspicuous strangulation in its base; a rather large gibbus maculae, with concave anterior and posterior outlines, narrower in the base than in the lateral margin; and the absence of an incisura lineae basalis. The gibbus maculae covers the prominentia marginalis completely on the ventral face, and forms a continuous regio apicale gibbi maculae on the dorsal one. However, the lapilli of each of the species can be identified by means of the following characteristics:

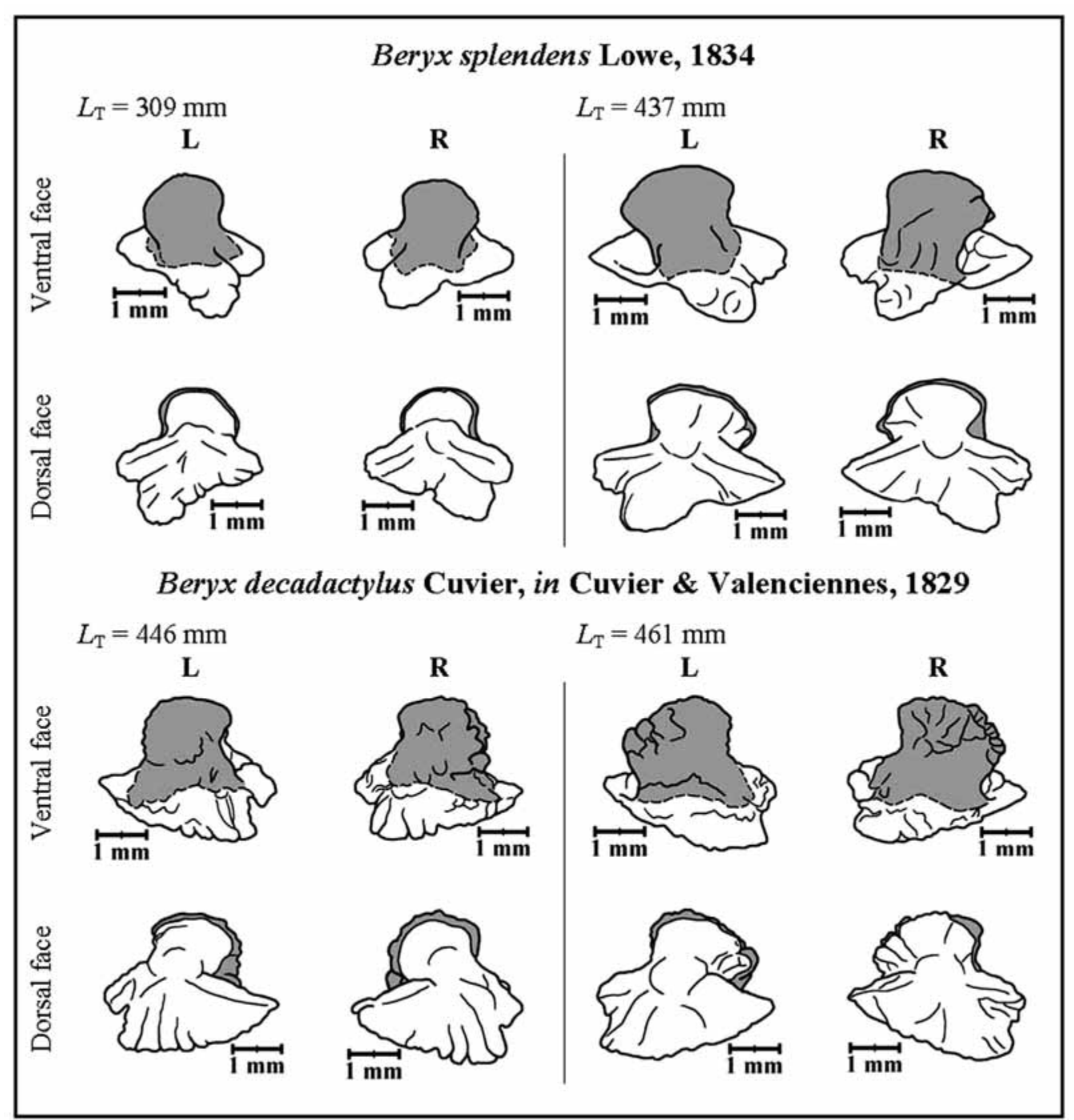

FIG. 11. - Ventral and dorsal faces of right (R) and left (L) lapilli of two species of genus Beryx (Berycidae) allowing a comparison between them. The shaded area corresponds to the gibbus maculae in the ventral face images, and to the regio apicale gibbi maculae in those of the dorsal face. All otoliths are represented with the lateral margin to the top of the page, and posterior region to the middle of each pair of columns (ventral face views), or to the outside of each pair of columns (dorsal face views). 
- Ventral surface of the otolith smooth. Medial side of the dorsal body divided into three almost equally sized lobes, separated by two conspicuous indentations. Constriction of the gibbus maculae close to its base, and equally distant from the lateral and the medial sides. Posterior part of the basal constriction of the prominentia marginalis as drastic and deep as the anterior one. Posterior region of the prominentia marginalis clearly expanded to the back. Beryx splendens

- Ventral surface of the otolith rough. Medial side of the dorsal body with two very unequally sized lobes, separated by one conspicuous indentation; the anterior lobe (corresponding to the anterior and middle lobes of $B$. splendens) much larger than the posterior one. Constriction of the gibbus maculae in its middle region, and clearly closer to the lateral side. Posterior part of the basal constriction of the prominentia marginalis less drastic and deep than the anterior one. Posterior region of the prominentia marginalis not expanded to the back. Beryx decadactylus

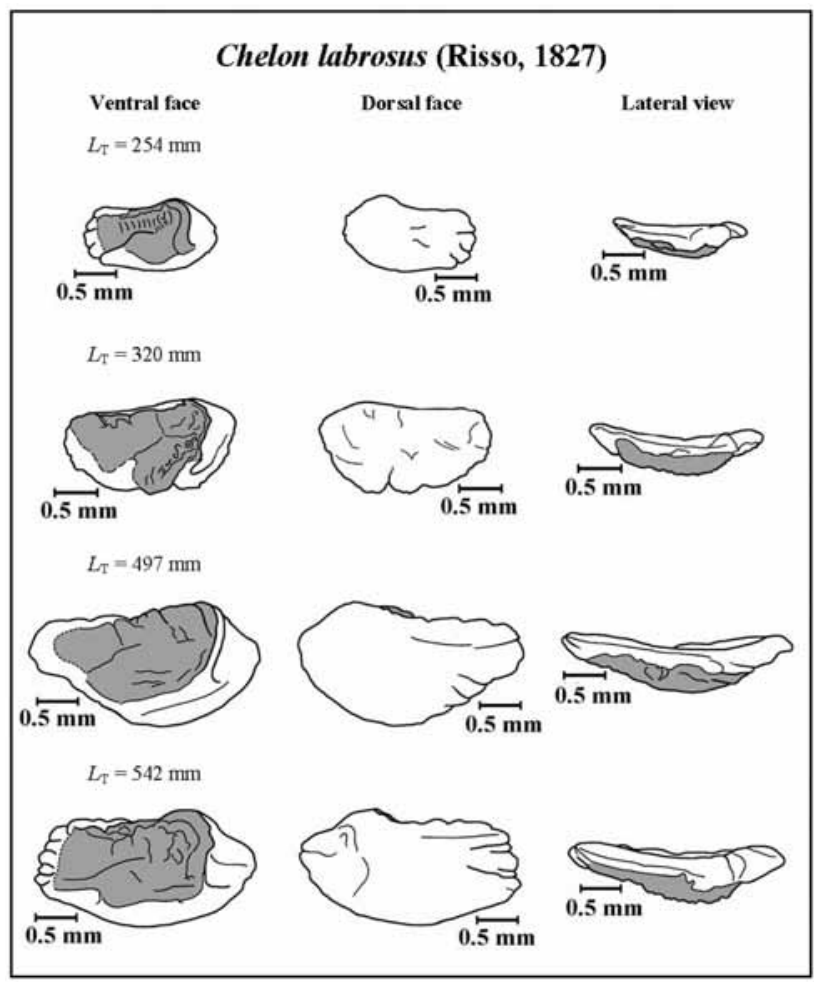

FIG. 12. - Three aspects of right lapilli from Chelon labrosus (Mugilidae) of four size classes. The shaded area corresponds to the gibbus maculae in the ventral face and lateral view images, and to the regio apicale gibbi maculae in those of the dorsal face. The otoliths are represented with the lateral margin to the top of the page and the anterior region to the middle of the first two columns (ventral and dorsal faces), or with the dorsal face to the top of the page and the anterior region to the right (lateral view).

\section{The lapilli of the Mugilidae}

The lapilli of four mugilid species (Figs. 12-15) are characterised by being oblong, almost semielliptical, with round and prominent anterior and posterior extremes. They have a small, premedian prominentia marginalis, perpendicular to the otoliths' longitudinal axis; and a rather asymmetrical gibbus maculae, with a premedian apex tilted towards the anterior direction.

Nevertheless, all species can be discriminated through the morphological characteristics of their otoliths. For this purpose, the following key can be used as a guide:

1 Profile of the dorsal surface of the otoliths, level or almost so. Incisura lineae basalis very deep and clearly tilted towards the anterior direction with an inclination similar to or greater than that of the apical region of the gibbus maculae; its posterior border marked by a conspicuous deep crevice-like cut on the surface of the otolith that reaches the posterior margin.........(genus Liza) 2

- Profile of the dorsal surface of the otoliths clearly concave. Incisura lineae basalis very shallow and almost perpendicular to the longitudinal axis of the otolith or, if tilted towards the anterior

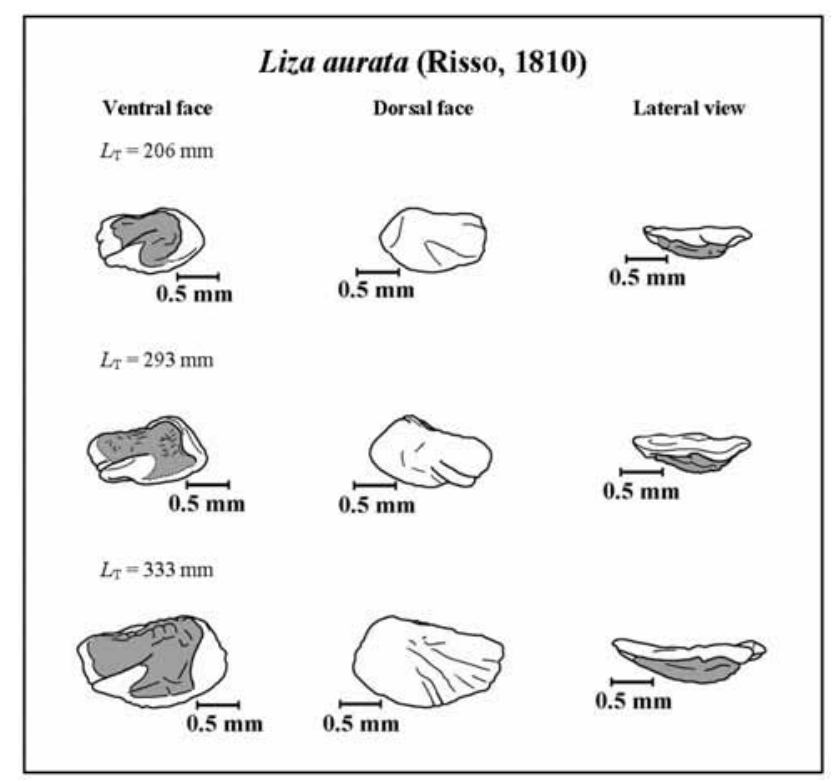

FIG. 13. - Three aspects of a right lapillus from Liza aurata (Mugilidae) of three size classes. The shaded area corresponds to the gibbus maculae in the ventral face and lateral view images and to the regio apicale gibbi maculae in those of the dorsal face. The otoliths are represented with the lateral margin to the top of the page and the anterior region to the middle of the first two columns (ventral and dorsal faces), or with the dorsal face to the top of the page and the anterior region to the right (lateral view). 


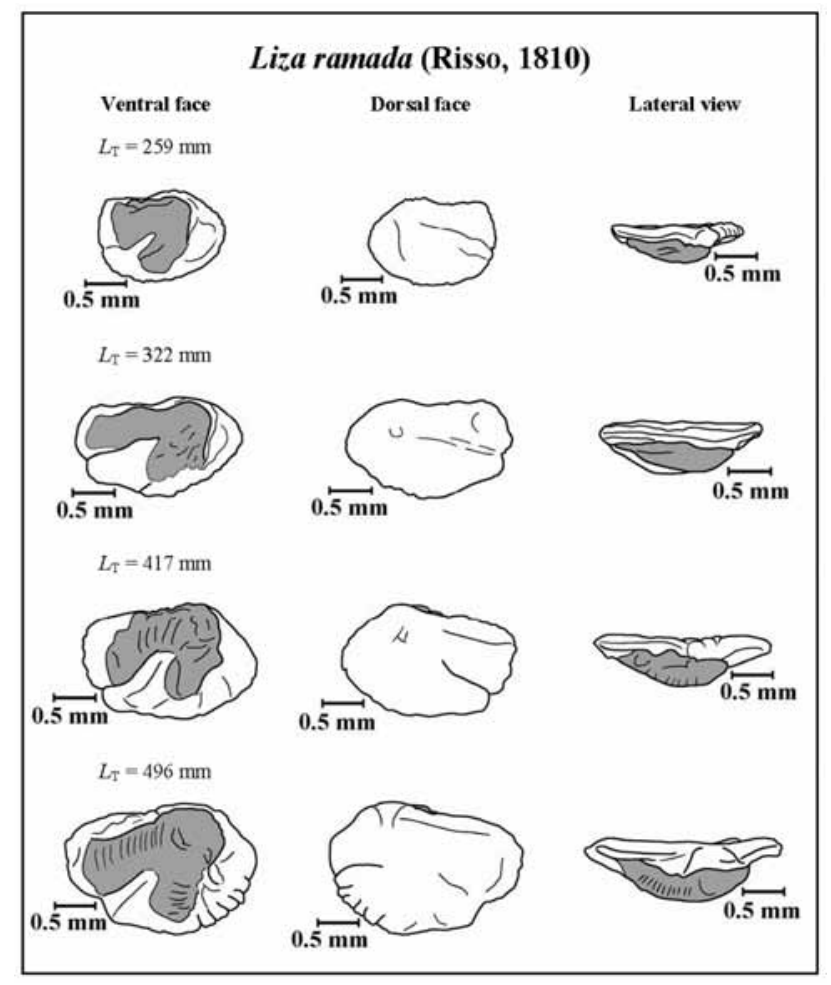

FIG. 14. - Three aspects of a right lapillus from Liza ramada (Mugilidae) of four size classes. The shaded area corresponds to the gibbus maculae in the ventral face and lateral view images and to the regio apicale gibbi maculae in those of the dorsal face. The otoliths are represented with the lateral margin to the top of the page and the anterior region to the middle of the first two columns (ventral and dorsal faces), or with the dorsal face to the top of the page and the anterior region to the right (lateral view).

direction, not as much as the apical region of the gibbus maculae; its posterior border never marked by a crevice-like cut on the surface of the otolith. .. 3

2 Extremum anterior clearly closer to the medial side of the otolith than to the lateral one. Incisura lineae basalis more inclined towards the anterior direction than the apical region of the gibbus maculae. Liza aurata

- Extremum anterior closer to the longitudinal midline of the otolith than to any of the sides. Incisura lineae basalis more or less coincident in orientation with the apical region of the gibbus maculae. Liza ramada

3 Extremum anterior close to the longitudinal midline of the otolith. Lateral profile of the gibbus maculae elevated over the dorsal body and covering the prominentia marginalis on the ventral face. Prominentia marginalis limited posteriorly by a deep and angulous indentation, covered by the posterior region of the gibbus maculae which forms a triangular regio apicale gibbi maculae in that region. Incisura lineae basalis almost per-

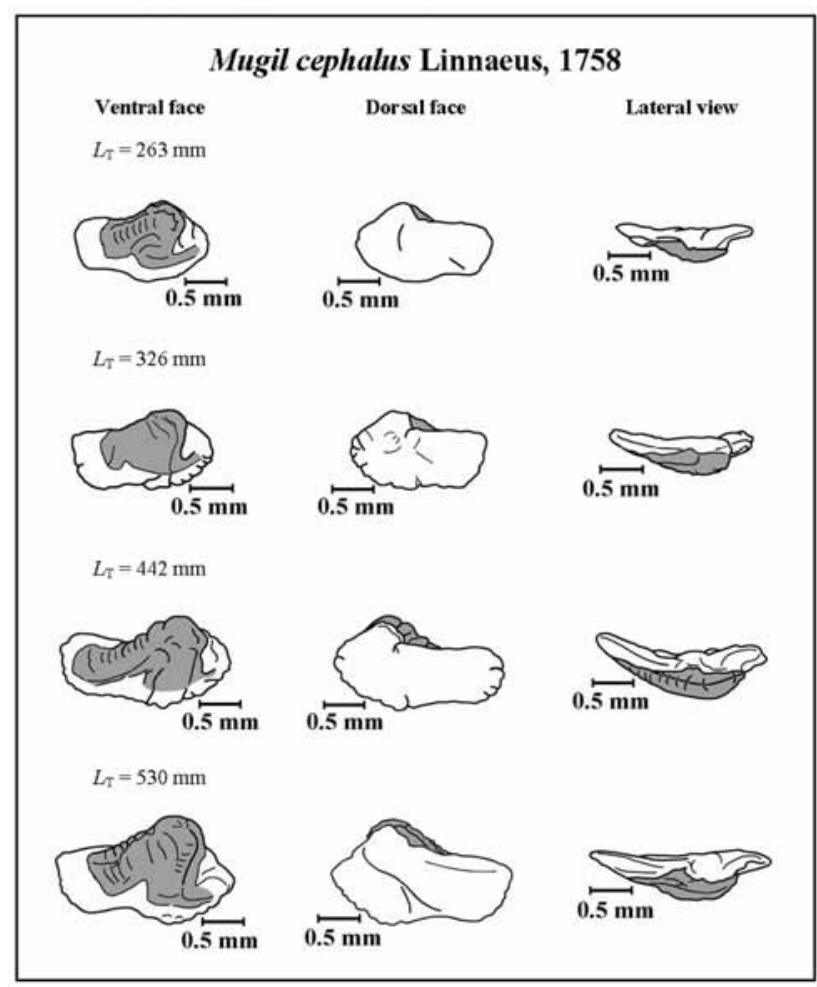

FIG. 15. - Three aspects of a right lapillus from Mugil cephalus (Mugilidae) of four size classes. The shaded area corresponds to the gibbus maculae in the ventral face and lateral view images and to the regio apicale gibbi maculae in those of the dorsal face. The otoliths are represented with the lateral margin to the top of the page and the anterior region to the middle of the first two columns (ventral and dorsal faces), or with the dorsal face to the top of the page and the anterior region to the right (lateral view).

pendicular to the longitudinal axis of the otolith. Mugil cephalus

Extremum anterior close to the lateral margin of the otolith. Lateral profile of the gibbus maculae not much elevated over the dorsal body, nor reaching the lateral margin of the otolith. Prominentia marginalis mild and not limited posteriorly by an indentation. Regio apicale gibbi maculae absent or almost negligible. Incisura lineae basalis inclined towards the anterior direction ...

Chelon labrosus

\section{The lapilli of the genus Diplodus and other Sparidae}

The ventral face of the left and right lapilli of several specimens belonging to five species of the genus Diplodus (Sparidae) are shown in Fig. 16. Common to all are the following characteristics: outline approximately rectangular and tilted towards the anterior direction; anterior and posterior regions round; prominentia marginalis and gibbus maculae premedian and pointing to an 


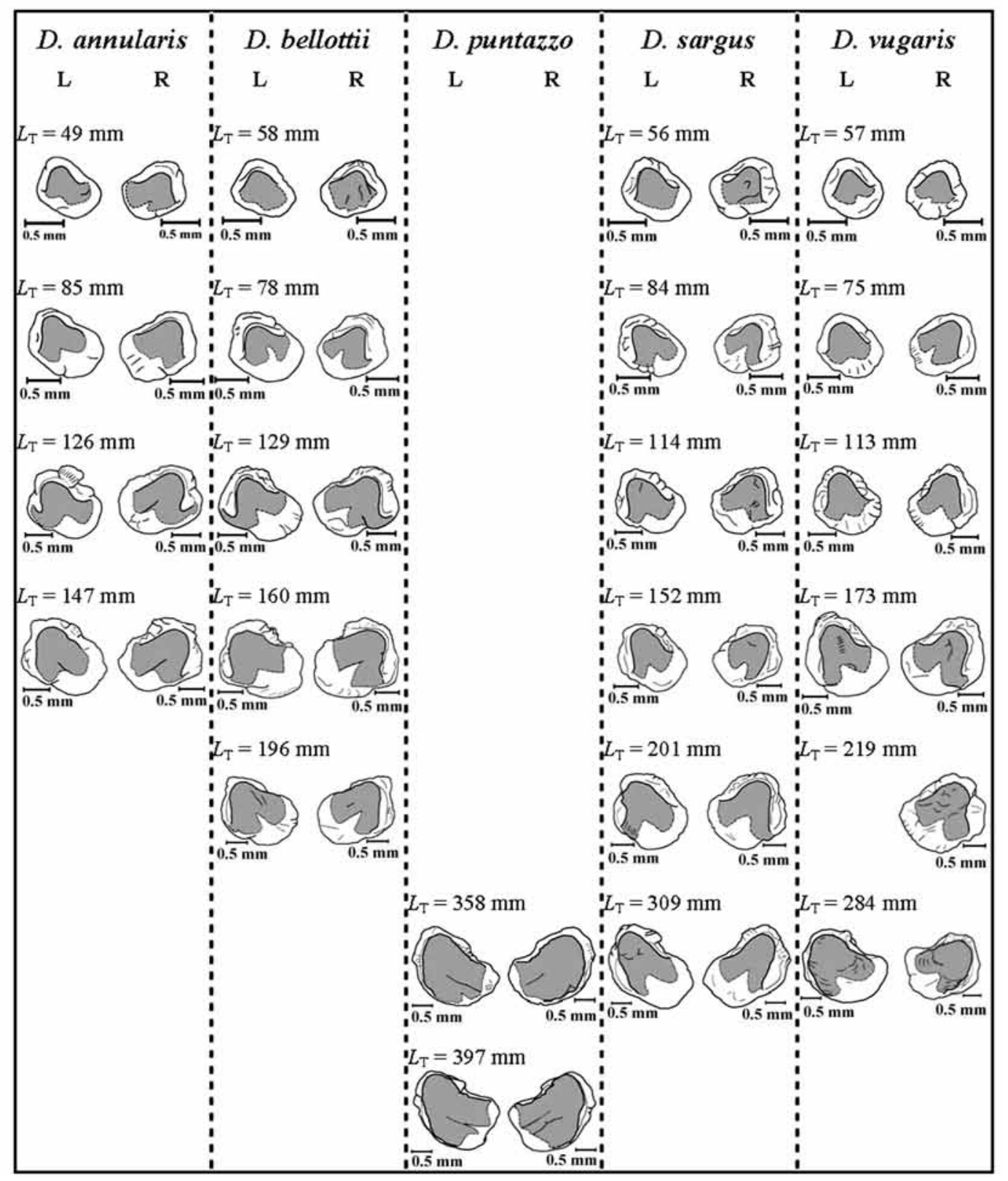

FIG. 16. - Ventral face of right (R) and left (L) lapilli of five species of genus Diplodus (Sparidae), illustrating some diversity within each species, and allowing a comparison between them. The otoliths are arranged according to the fishes' total length $\left(L_{\mathrm{T}}\right)$ classes. The shaded area corresponds to the gibbus maculae. All otoliths are represented with the lateral margin to the top of the page, and the posterior region to the middle of each species column.

antero-lateral direction; and outline of the gibbus maculae approximately symmetrical and regularly curved.

Apart from that, some characteristics of the gibbus maculae, such as its thickness and elevation in relation to the dorsal body; and of the linea basalis, namely its clarity and the depth of its incisura, become more noticeable with the increase in fish length. Although only 3 species are represented by otoliths from larger sized fish, it seems that the increase in size brings about a reduction in the anterior region of the otolith (the extremum anteri- or becomes progressively less conspicuous) and a relative increase in the longitudinal axis of the otolith.

Although the differences between the otoliths of the various Diplodus species are not as clear as in the examples presented before, which may lead to a larger percentage of misidentified specimens, especially for specimens smaller than $70 \mathrm{~mm}$, as they have not yet developed the most important differentiating characters, the following key can be used to discriminate between the larger specimens of the Diplodus species represented: 


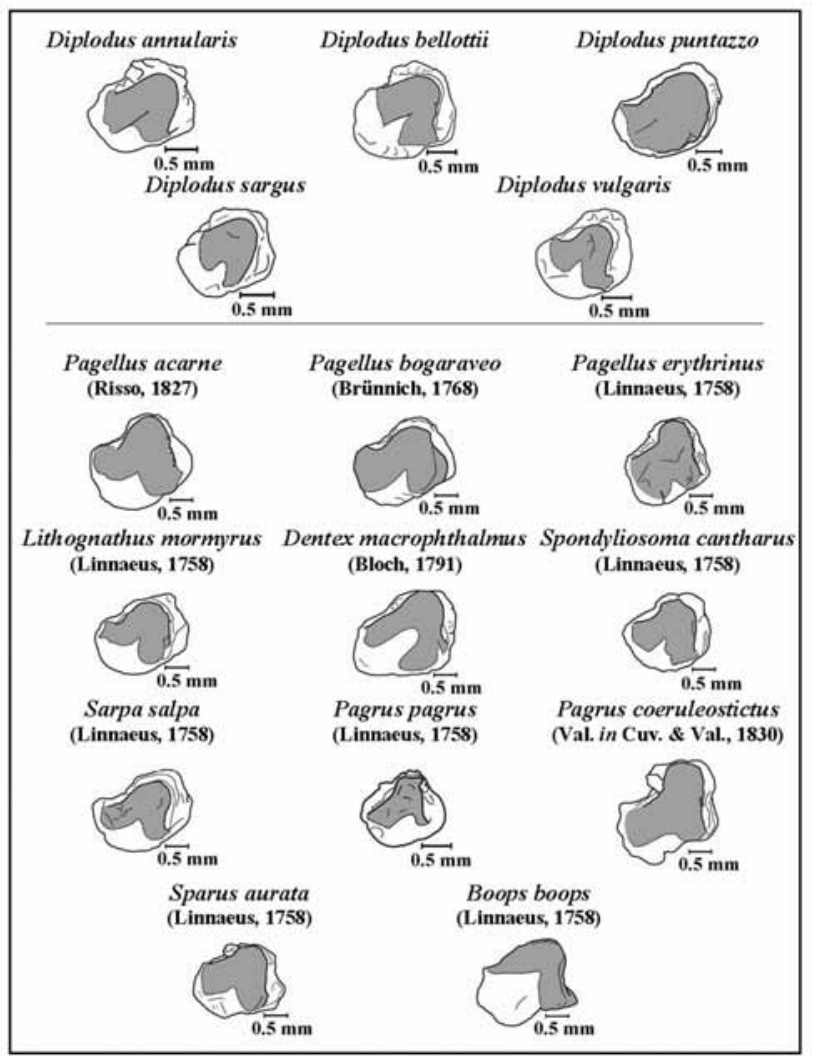

FIG. 17. - Ventral face of the right lapilli of five species of genus Diplodus and of several other species of the family Sparidae, to allow a comparison between them. The shaded area corresponds to the gibbus maculae. All otoliths are represented with the lateral margin to the top of the page and anterior region to the right.

1 Lateral outline of the gibbus maculae clearly asymmetrical: anterior outline convex and posterior outline concave, covering almost completely the ventral face of the dorsal body. Linea basalis close to the margin of the otolith, without an incisura lineae basalis. Extremum anterior round and not salient in the anterior profile

D. puntazzo

- Lateral outline of the gibbus maculae approximately symmetrical, both anterior and posterior outlines slightly concave, covering only part of the ventral face of the dorsal body. Linea basalis far from the posterior region of the medial margin of the otolith, with a conspicuous incisura lineae basalis. Extremum anterior round but salient in the anterior outline

.. 2

2 Dorsal body of the otolith more rectangular than round in shape. Medial margin less convex than the lateral one; longitudinal axis, at the level of the anterior and posterior extremes of the otolith, closer to the medial side. Gibbus maculae wider at the base than long. Anterior region of the base of the gibbus maculae with a strong bend towards the extremum anterior. (D. annularis / D. bellottii) 3

- Dorsal body of the otolith more round than rectangular in shape. Medial margin more convex than the lateral one; longitudinal axis, at the level of the anterior and posterior extremes of the otolith, closer to the lateral side. Gibbus maculae as wide at the base as long. Anterior region of the base of the gibbus maculae without a bend towards the extremum anterior...

(D. sargus / D. vulgaris) 4

3 Lateral outline of the gibbus maculae only slightly elevated in relationship to the dorsal body of the otolith. Incisura lineae basalis shallow and round, with sides forming an obtuse angle and apex with an orientation different from that of the apical region of the gibbus maculae.

D. annularis

- Lateral outline of the gibbus maculae rather elevated in relationship to the dorsal body of the otolith. Incisura lineae basalis deep and angulous, with sides forming an acute angle and apex with the same orientation as the apical region of the gibbus maculae. D. bellottii

4 Posterior side of the incisura lineae basalis deeply cut and very clear, but anterior side almost inconspicuous. Sections of the medial margin of the dorsal body separated by a clear curve or angle. Anterior branch of the basal region of the gibbus maculae narrower than the posterior one.

D. sargus

- Both sides of the incisura lineae basalis very clear and elevated. Medial margin of the dorsal body with a continuous and regular curve; its sections not separated by a clear curve or angle. Anterior branch of the basal region of the gibbus maculae as wide as the posterior one

D. vulgaris

Comparing the otoliths of these Diplodus species with other sparid species (Fig. 17), it is noticeable that although with the same basic structure, otoliths of some of the species are considerably different, to the point that a complete discrimination between them is possible.

The most important distinctive features are the outline of the anterior and medial margins, the shape of the anterior and posterior regions, the relative position of the extremes and that of their longitudinal axis, the outline of the gibbus maculae, and the depth, width and shape of the incisura lineae basalis. 
